Research Note

Journal of Extension Education

Vol. 29 No. 3, 2017

DOI:https: / / doi.org/10.26725/JEE.2017.3.29.5917-5920

\title{
Communication Behaviour of Cashew Cultivators
}

\author{
K. Kanagasabapathi ${ }^{1}$ and V. Sakthive ${ }^{2}$
}

\begin{abstract}
In a country like India where agriculture is the main occupation, communication can serve better for the cause of development. Cashew being one of the important cash crops, proper communication strategy need to be devised to reach the cashew cultivators to improve the cashew production and productivity. Keeping this in mind, the present study was taken-up to analyse the communication behaviour of cashew farmers. A sample of 120 cashew farmers were selected from Panruti taluk of Cuddalore district, Tamil Nadu using simple random sampling technique. The data were collected using a well structured interview schedule and analysed with appropriate statistical tools. Regarding communication behaviour, among personal cosmopolite sources, Rural Welfare Officer \& Block development officials were the mainly utilized sources by the respondents for getting information on cashew. Among the personal localite sources, Panchayat offices and Primary Co-operatives were the most used sources by the respondents for getting information on cashew.
\end{abstract}

Keywords : Communication; Information processing; Information storage; Information output; cashew cultivators.

Cashew nut cultivation assumes special significance as it is being grown in dry tracts of Tamil Nadu providing income to small and marginal farmers. Tamil Nadu occupies second place in terms of area under Cashewnut in the country. However its production accounted only for seven per cent of the country's production due to low productivity. Communication has attained great importance in the community development and extension programmes.
It is through this process that aims and objectives of the programmes are to be widely disseminated to the people and useful informations are passed to them to solve their problems (Baskaran and Rao, 1985). This necessitates that the extension workers should have a thorough understanding of the communication process, to influence the farmers for adopting modern recommended technologies (Dubey and Bisnol, 2008) Hence, an attempt

1. Professor \& Head and 2. Assistant Professor, Department of Agricultural Extension, Faculty of Agriculture, Annamalai University, Annamalainagar - 608002.

Received : 21-09-2017; Accepted : 13-02-2018 
was made to study the communication behaviour of cashew farmers with the specific objective of studying information input behaviour, information processing behaviour and the information output beahviour of cashew cultivators.

\section{METHODOLOGY}

Cuddalore district has the maximum area under cashew in Tamil Nadu State. Panruti taluk has the highest area in cashew cultivation in this district and hence it was purposively selected for the study. Six villages were selected based on their higher area in cashew cultivation. A sample of 20 cashew farmers was randomly selected

from each village to have a sample size of 120 representing all the six villages for the study. A well-structured and pretested interview schedule was used for the collection of data .The data collected were processed, coded and tabulated for statistical analysis. Descriptive statistics analyses and correlation analysis were used for meaningful interpretation of data.

\section{FINDINGS AND DISCUSSION}

\section{a) Information Input Behaviour}

The extent of utilization of various information sources by cashew cultivators is presented in Table - 1 .
Table 1.

Information Sources used by Cashew Cultivators

\begin{tabular}{|c|c|c|}
\hline $\begin{array}{l}\text { S1. } \\
\text { No. }\end{array}$ & Information Sources & $\begin{array}{c}\text { Percen } \\
\text { tage } \\
(n=120)\end{array}$ \\
\hline $\mathbf{I}$ & Personal Cosmopolite & \\
\hline 1. & Rural welfare officer & 97.50 \\
\hline 2. & $\begin{array}{l}\text { Block development } \\
\text { officials }\end{array}$ & 94.16 \\
\hline 3. & Demonstrations & 67.50 \\
\hline 4. & Campaign meetings & 36.66 \\
\hline 5. & Farmer's training & 35.83 \\
\hline \multirow[t]{2}{*}{6.} & Query letters & 20.83 \\
\hline & Mean & 59.00 \\
\hline II & Personal-Localite & \\
\hline 1. & Panchayat offices & 88.33 \\
\hline 2. & Co-operative society's & 69.16 \\
\hline 3. & Progressive farmers & 29.16 \\
\hline 4. & Input merchants & 27.50 \\
\hline 5. & Friends and neighbours & 20.00 \\
\hline 6. & School teachers & 17.50 \\
\hline 7. & Relatives & 9.16 \\
\hline \multirow[t]{2}{*}{8.} & Money lenders & 0.83 \\
\hline & Mean & 33.00 \\
\hline III & Impersonal Cosmopolite & \\
\hline 1. & Farm radio broadcast & 95.83 \\
\hline 2. & Posters and charts & 94.16 \\
\hline 3. & Agricultural films & 92.50 \\
\hline 4. & Tea shop boards & 86.66 \\
\hline 5. & $\begin{array}{l}\text { Written information } \\
\text { material }\end{array}$ & 80.83 \\
\hline 6. & Newspapers & 52.50 \\
\hline 7. & Leaflets and bulletins & 29.16 \\
\hline \multirow[t]{2}{*}{8.} & Popular farm magazines & 9.16 \\
\hline & Mean & 67.00 \\
\hline
\end{tabular}


all the personal cosmopolite sources. Among them, 'Rural Welfare Officers', 'Block development officials' and 'Demonstrations' were the three personal cosmopolite sources predominately contacted by more number of respondents for getting information on cashew cultivation practices, inputs, marketing strategies etc.,

Regarding personal localite sources the farmers contacted 'Panchayat offices', 'Co-operative societies', 'progressive farmers' and 'input merchants' as sources of information in more proportion regarding cashew cultivation and marketing aspects.

From the table, it may also be noted that all the eight impersonal cosmopolite sources were used in different proportions by 9.16 to 95.83 percent of respondents. The impersonal cosmopolite sources used by farmers were farm broadcast, posters and charts, agricultural films, tea-shop boards, written information materials, newspapers, leaflets and bulletins and popular farm magazines.

\section{b) Information Processing Behaviour}

Information processing behaviour of cashew cultivators is presented under two sub-divisions namely information evaluation and information storage.

\section{i) Information Evaluation}

Generally farmers are likely to evaluate the information in consultation and discussion with other farmers immediatelyafter receiving theinformation
(Laksmidevi, 2004).In addition, before deciding to use the information gathered, they also analyse the merits and demerits of the information received by them.

Table 2.

\section{Methods of Evaluation of Information} used by Cashew Cultivators

\begin{tabular}{|c|l|c|}
\hline $\begin{array}{c}\text { S1. } \\
\text { No. }\end{array}$ & Methods of Evaluation & $\begin{array}{c}\text { Percen } \\
\text { tage } \\
\text { (n=120) }\end{array}$ \\
\hline 1. & $\begin{array}{l}\text { Discussed with family } \\
\text { members }\end{array}$ & 85.83 \\
\hline 2. & $\begin{array}{l}\text { Discussed with friends } \\
\text { or neighbours }\end{array}$ & 83.33 \\
\hline 3. & Discussed with relatives & 72.50 \\
\hline 4. & $\begin{array}{l}\text { Considered availability } \\
\text { of seeds, fertilizers and } \\
\text { inputs }\end{array}$ & 64.16 \\
\hline 5. & $\begin{array}{l}\text { Discussed with } \\
\text { progressive farmers }\end{array}$ & 63.33 \\
\hline 6. & $\begin{array}{l}\text { Discussed with input } \\
\text { agents }\end{array}$ & 60.83 \\
\hline 7. & $\begin{array}{l}\text { Discussed with Rural } \\
\text { Welfare Officer }\end{array}$ & 60.00 \\
\hline 8. & Considered suitability & 60.00 \\
\hline 9. & $\begin{array}{l}\text { Considered ease in } \\
\text { operation }\end{array}$ & 53.33 \\
\hline 10. & $\begin{array}{l}\text { Observed } \\
\text { demonstrations and } \\
\text { fields growth by others }\end{array}$ & 51.66 \\
\hline 11. & Considered profitability & 50.00 \\
\hline 12. & $\begin{array}{l}\text { Discussed with } \\
\text { block level extension } \\
\text { personals }\end{array}$ & 50.00 \\
\hline 13. & $\begin{array}{l}\text { Discussed with school } \\
\text { teachers }\end{array}$ & 40.83 \\
\hline 14. & Conducted trials & 23.33 \\
\hline
\end{tabular}




\section{ii) Information Storage}

After the evaluation of the information received, storage of the information is indispensable for its future use. Table 3 reveals the different methods of storage of information used by the cashew cultivators.

Table 3.

Methods of Information Storage used by Cashew Cultivators

\begin{tabular}{|c|l|c|c|}
\hline $\begin{array}{r}\text { S1. } \\
\text { No. }\end{array}$ & \multicolumn{1}{|c|}{ Methods of Information storage } & Number & $\begin{array}{c}\text { Percentage } \\
\text { (n=120) }\end{array}$ \\
\hline 1. & By memorising & 117 & 97.50 \\
\hline 2. & By informing to family members to keep in mind & 112 & 93.33 \\
\hline 3. & By making note in a specified notebook & 70 & 58.33 \\
\hline 4. & By keeping leaflets, handouts, etc. in a specified safe place & 60 & 50.00 \\
\hline 5. & By making note in a common note book & 50 & 41.66 \\
\hline
\end{tabular}

Memorising was the most commonly used method for information storage by majority of the respondents. 'Informing to family members to keep in mind' was the second most used Method.

\section{c. Information Output Behaviour}

The results of information output behaviour of cashew cultivators revealed that, 'Relatives' was the category of persons with whom most of the respondents (95.83 per cent) shared the information. 'Neighbours' and 'friends' were found to be the second and third type of persons with whom majority of the respondents (89.16 percent and 63.33 per cent, respectively) shared information.

\section{REFERENCES}

Baskaran, C \& Sethu Rao, M. K. (1985). Correlates of Interpersonal Communication Behaviour of Farmers in Differentially Progressive Villages.
Indian Journal of Extension Education, 21 (3 \& 4): 76-79.

Dubey, V.K \& Bisnol, I. (2008). Extension Education and Communication. New Delhi: New Age International Publishers.

Laksmidevi, R. (2004). Communication Behaviour of Women Leaders in Cuddalore District. Unpublished M.Sc. (Ag.) Thesis, Department of Agricultural Extension, Annamalai University, Annamalai Nagar.

Leagans, J.P. (1961). The Communication

Process in Extension Education in Community Development. New Delhi: Directorate of Extension, Govt. of India, pp. 362-91.

Loomis, Chals P \& Beagle J, Allen. (1950) Rural Social System - A Text book in Rural Sociology, New York; Prentice Hall. 